\title{
SANTRIPRENEURSHIP: INTERNALIZING THE VALUES OF INDEPENDENCE IN THE DIGITAL ERA (CASE OF PONDOK PESANTREN IN MALANG RAYA)
}

\author{
Iva Khoiril Mala*1, Heri Pratikto*), and Agung Winarno*) \\ *) Universitas Negeri Malang \\ Jl. Semarang No.5, Sumbersari, Kota Malang 65145, Indonesia
}

\begin{abstract}
This study aimed to reveal the process of internalizing the self-reliance values of santri in the digital era at pondok pesantren Malang Raya, East Java. The approach of this study was descriptive and qualitative. The data were collected through in-depth interviews and observations with the respondents consisting of three kiai, five board of pondok pesantren, three teachers, and eight students. The data analysis used a simultaneous stage model consisting of approach, extracting, deepening, matching, interpretation, and presentation. The results showed that the character values implanted were the values of independence, namely not depending on others and not oriented to the company/employee organization. The value cultivation system was carried out using the kiai's teachings through learning based on the available ulama books and practical assignments to assist trading businesses, product processing, and services in pondok pesantren's cooperative. Utilization and understanding of the use of internet technology is very appropriate in the context of reducing the character ordering morality.
\end{abstract}

Keywords: digital era, obedience to kiai, santri, values of independence

Abstrak: Penelitian ini bertujuan untuk mengungkapkan proses-proses internalisasi nilai-nilai kemandirian kepada para santri di era digital pada pondok pesantren di wilayah Malang RayaJawa Timur. Pendekatan penelitian adalah deskriptif dan kualitatif. Pengumpulan data dilakukan melalui wawancara mendalam dan observasi dengan informan para tiga kiai, lima pengurus pondok, tiga guru, dan delapa santri. Analisis data menggunakan model tahapan simultan yang terdiri dari pendekatan, penggalian, pendalaman, pencocokan, intrepretasi dan presentasi. Hasil penelitian menunjukkan nilai-nilai karakter yang ditanamkan adalah nilai kemandirian yang tidak bergantung dengan orang lain dan tidak berorientasi kepada karyawan / organisasi. Sistem penanaman nilai dilakukan doktrin oleh kiai kepada santrinya melalui pembelajaran yang berbasis kitab ulama yang tersedia, melalui penugasan praktek membantu usaha dagang, pengolahan produk dan jasa dalam wadah badan usaha koperasi pesantren. Pemanfaatan dan pemahaman penggunaan teknologi internet sangat tepat dalam rangka pengurangan rangka reduksi akhlak pemesanan karakter.

Kata kunci: era digital, ketaatan pada kiai, nilai kemandirian, santri

${ }^{1}$ Corresponding author:

Email: ivamala180496@gmail.com 


\section{INTRODUCTION}

In the industrial revolution 4.0 era, the demand for a state to move forward is one reason for improving human resources, especially those in productive age. Every industrial revolution brings benefits and challenges to a country's socio-economic status, including the impact of the ongoing industrial revolution 4.0. Merkel (2014) argued that industry 4.0 is a comprehensive transformation of all aspects of the production in industries through digital and internet technology, combined with conventional industries. Schlechtendahl et al. (2015) emphasized the speed of information availability, namely the industrial environment in which all entities are always connected and can share information. Based on this statement, the development of the industrial revolution 4.0 is marked by the rapid development of Information and Communication Technology (ICT), so that the industrial revolution 4.0 is also called the digital era or the information democratization era. The impact of information democratization is the widest possible openness to something, and there is no more confidentiality on the other side (Prisgunanto, 2014). In the digital era, the strong spirit of democratizing information creates euphoria in human behavior in using information. It has become a concern in several studies on communication and the digital world. Through an easy information center ownership, especially the conventional mass media (mainstream), and the emergence of e-government caused information flow to be so swift and unstoppable because everyone was free to create and use information. In the digital era, everyone can become a producer of information (Safko, 2010). Therefore, the mastery of technology is a demand and a driving factor in developing HR's quality in this era amid the rapid development of information. Human resources, who are considered capable of mastering technology quickly, namely those born during the industrial revolution, develop rapidly. These HRs are generation $\mathrm{Z}$ or groups of people born after 2000 to the next few years whose boundaries cannot be determined (Kupperschmidt, 2000). In this connection, generation $\mathrm{Z}$, as human resources who will build the nation's civilization, ideally must master soft skills or abilities that are affective and psychomotor. Soft skills include critical thinking, problem-solving, communication, collaboration, and creativity/discovery. Generation $\mathrm{Z}$ must master all or some of these soft skills to compete in the digital era. Soft skills mastery also needs to be balanced with adequate technology mastery to achieve superior and quality human resources and social life benefits.

This study's purpose was to create superior and quality human resources as generation $\mathrm{Z}$ demands are increasing in this digital era. Since the industrial revolution occurred, all activities that could previously be carried out with conventional interactions are now obliged to include government recommendations with technological developments complemented by activities that must be carried out online. For example, trade transactions shifted from cash payment to online payment; public services shifted from face-toface procedures to applications on smartphones; the community's social activities shifted from direct to limited or even online activity. This shifting also has an impact on a more advanced education system. However, based on the researchers' facts, there are obstacles, specifically in pondok pesantren, namely the limited use of the internet for independent learning. There is a tradition of obedience to leaders/kiai that makes them implement a service system rather than entrepreneurship after graduating. With the support of pondok pesantren facilities, such as the businesses managed by pesantren, some students decide to manage businesses located in pesantren.

Online learning activities are a form of adjustment to the digital era's education system to produce generation $\mathrm{Z}$ who are competent and have good soft skills. The competency/soft skill that generation $\mathrm{Z}$ must own in the digital era is having a passion for entrepreneurship. Entrepreneurship is an alternative that can be done by generation $\mathrm{Z}$ to be able to compete in the digital era. Cho et al. (2018) stated that generation $Z$ has a higher entrepreneurial spirit (17\%) compared to generation Y (11\%). So that global employment opportunities for generation $\mathrm{Z}$ will be even greater. Generation $\mathrm{Z}$ is excited to acquire relevant knowledge and skills to enhance their future career goals. Therefore, the spirit and interest in entrepreneurship, exploring knowledge, and improving skills must be optimized. Optimization efforts in enhancing the entrepreneurial spirit can be done by internalizing the values of independence for generation $\mathrm{Z}$.

Theinternalization ofindependence values implemented by pondok pesantren towards generation $\mathrm{Z}$ can be integrated according to the 21 st-century learning 
vision. In accordance with the educational context that implements the 21st-century learning vision, UNESCO has made four educational pillars, namely: 1) Learning to know, 2) Learning to do, 3) Learning to be (learning to actualize oneself as an independent and personality individual), 4) Learning to live together. Education that builds 21 st-century competencies uses a 21 st-century learning framework that requires students to have the knowledge, learning skills, life skills, innovation, and abilities in technology, media, and information (Kemendikbud, 2018).

The learning activities implemented in pondok pesantren system have various components. According to Nafi et al. (2007), the education system implemented by pondok pesantren is seen as a discipline of tawhid (a complete view), comprehensive, and integrated regarding life, the world, learning, children, and others. Its content components are customary subjects, direct information, not paying attention to its relevance to student life, only teaching (ta'lim), tarbiyah (characterbased), leading to transformation, connecting the real world, and making the book of life as the curriculum. The structural component is an obscure and incoherent structure, structured by a particular academic discipline, strong ideas, big ideas that can inspire and change, the building blocks of character and personality, and curricular. The method components are didactic (words and lectures), teachers as determinants/wise men, assembly machine models, one size fits all, unattractive, discovery learning, student-centered, different teaching, various learning styles, teachers as guides, modeling and monitoring, and integrated learning models (ILM). The program components are focus on the past and Islam as a religion, performing Islamic rituals, the mystery of life is the current focus, being Muslim, Islam as a way of life (being Islamic), and Islam for the mystery of life. The objective component is to obtain information, knowledge, and skills, especially for work and entrepreneurship, outside of school (how to learn, learn for life and afterlife, and complete human development). The assessment components are pencil and paper, true/false, pass/fail, standardized assessment, authentic assessment, and authentic work.

Based on the pondok pesantren education system, several factors form the curriculum's basis so that the educational process goes one way. The curriculum applied in pondok pesantren is the development of science and technology, the community's needs, students' rights as Muslims and citizens, pesantren managers' capacity, the mission of the pesantren, government policies, and the synergy of these factors. Thus, the self-reliance internalization carried out by pondok pesantren through the education system and curriculum support will run effectively.

Basically, the internalization of independence values can be applied at all levels and educational institutions. One form of internalization of self-reliance values that appear to be superior among educational institutions happens in pondok pesantren. For Indonesian, pondok pesantren is a means of developing the quality of human resources that must be implemented. The development of human resources' quality in pondok pesantren will significantly contribute to improving people's lives in the future (Halim et al. (2005). Based on this statement, pondok pesantren are expected to prepare several actualization programs to develop the quality of human resources and improve the community's quality of life. Pondok pesantren have also contributed to the increased business interests of students through entrepreneurship education. The form of entrepreneurship education that students can apply through the internalization of independence values from pondok pesantren is called santripreneurship.

In essence, entrepreneurship education has developed rapidly over the past two decades. Although several decades ago, some argued that entrepreneurship could not be taught, nowadays, entrepreneurship is a subject that can be taught in schools (Ruskovaara et al. 2015). Many countries have started introducing policy frameworks to support entrepreneurship education and training, as happened in Indonesia. Currently, entrepreneurship education has begun to be taught at the elementary, junior high school, senior high school, pondokpesantren, and even in business and management courses in Indonesia. The prospect of entrepreneurship education in the future is that it can increase the number of Indonesian entrepreneurs that is categorized low. Indonesia currently needs young entrepreneurs to be able to support the country's economic growth. The number of entrepreneurs in Indonesia reached $0.24 \%$ of the total population ( 240 million), while others prefer to become employees or civil servants. This figure is lower than entrepreneurs in several countries with high economic growth rates, such as the United States, which reached 11\%, Singapore 7\%, and Malaysia 5\% (Alma 2018). Regarding the internalization of independence values, pondok pesantren also develops students' potential to become young entrepreneurs. Efforts to 
build the entrepreneurial spirit of the santri are adjusted to the pondok pesantren curriculum. Pondok pesantren curriculum is prepared based on the Islamic boarding school's educational objectives, namely shaping students' personalities (Abdullah, 2010).

The leadership of a kiai also supports the formation of the santri's personalities. The leadership of the kiai is the most important element of pondok pesantren. Naturally, the development of pondok pesantren only depends on the personal abilities of the kiai (Dhofier, 2015). The role of the kiai is very influential on the survival of the students. The mindset embedded in students is to serve the kiai to become successful students in the world and the hereafter. Most of the kiai argue that pondok pesantren can be likened to a small kingdom where kiai is a source of absolute power and authority in pondok pesantren's life and environment. The students always hope and think that the kiais are people who fully believe in themselves (self-confidence), both in terms of Islamic knowledge and in the power of managing pesantren funds (Dhofier, 2015). Therefore, the kiais' intervention will increase students' self-confidence to develop their talents in entrepreneurship.

The three objectives of pondok pesantren education are added to the efforts to realize the entrepreneurial potential of the santri and internalize the values of independence applied by pondok pesantren. However, based on the collected data, it turned out that these efforts did not match the Islamic boarding school's expectations. It was known that most students had a low interest in entrepreneurship. They have other plans to develop their potential, namely by serving pondok pesantren by opening independent businesses or opening businesses with pondok pesantren as investors. All forms of santri's plans in entrepreneurship and their future will receive full support from pondok pesantren as long as they are sufficiently equipped to compete in the digital era to become independent entrepreneurs. Based on some of the problems described above, santripreneurship is an effort that can demonstrate the existence of pondok pesantren to produce quality students by internalizing the values of independence. This research examined the forms of businesses run by pondok pesantren, analyzed the efforts to internalize the values of independence applied by pondok pesantren, analyzed the supporting and inhibiting factors of efforts to internalize the values of independence applied by pondok pesantren in the digital era.

\section{METHODS}

This research was conducted in eight pondok pesantren in Malang Raya, namely Pondok Pesantren Al-Hikam Malang, Pondok Pesantren Bahrul Maghfiroh, Pondok Pesantren Al-Ishlahiyah Singosari, Pondok Pesantren An-Nur 2 Bululawang, Pondok Pesantren Kazunnajah, Pondok Pesantren Nurul Ulum, Pondok pesantren Mamba'ul Ulum Batu, and Pondok Pesantren Sabilurrosyad Gasek. The research period started from December 2019 to June.

This research used primary and secondary data. Data sources can differ from people, places, and references (Yin, 2002). Primary data can be obtained from interviews with informants or individuals (Creswell, 2012). Primary data in this research were collected through open questionnaires, in-depth interviews, and activity observations. The existence of the event, message, and focus of the tested problems were treated naturally and concentrated on an intensive and profound event. Data can also be obtained from changes in the activity of respondents (santri) directly in pondok pesantren (observation). There were twentyfour respondents from pondok pesantren, namely ustaz/ ustazah, students (santri), and the pesantren's head.

The correctness of data and information is real, as the data were based on assessment methods. Meanwhile, information is obtained from data processing used as needed. The data shows that a study is divided into three types, namely facts, opinions, and skills (Matthew, et al. (1994). The data used in this study is a collection of facts from the research object in the form of words (statements), actions, and documentation that can be used to support research findings.

The main techniques used when collecting data in qualitative research are interviews, observation, documentation, and audiovisual material. In this study, the audiovisual material was a webinar on the financial management of pondok pesantren based on Information Technology (IT), which supports pondok pesantren's independence. According to Creswell (2012), several steps undergone regarding the data collection process were as follows: 1) Identifying the participants and locations to be studied; 2) Obtaining access to multiple people and locations to get permission; 3) Identifying the types of respondents who can answer the researcher's questions; 4) Designing research instruments to collect and record information; 5) Organizing the data that had 
been collected according to its categories into potential ethical problems (economic, physical, and mental problems) that could be raised.

After conducting observation and interviews, qualitative data were presented in three stages, namely data reduction, data presentation, and conclusion drawing. In order to provide more accurate data, data validity was also tested using data triangulation techniques, namely by analyzing the data one by one as a whole, then adjusting the results of the analysis to support the main literature. Data analysis used in this study were approach, extracting, deepening, matching, interpretation, and presentation (6P).

The methods used in this research were qualitative and descriptive. In this method, there is an explanation of the input, process, and output. This method is illustrated through a simple research design by the researcher in Figure 1.

The research design was modified to make it more detailed by providing explanations of problem description, research focus, and research instruments for data analysis. Therefore, the researcher made the research design described in Figure 2. Systematically, this research is based on a case study related to gathering information from individuals, groups, and social communities. The objectives of using a case study in this research are as follows: 1) In-depth and examining an event (case). In this connection, this research aimed to identify the strategy of independence values internalization of several pondok pesantren in Malang Raya as provisions for students in the digital era; 2) Linking one case to another case with the hope of obtaining entrepreneurship education data in pondok pesantren as a basis for building an entrepreneurial spirit for students; and 3) Investigating unique phenomena.

\section{RESULTS}

This research was conducted based on a study of the digital era's phenomenon that has influenced various aspects of people's lives, especially those related to the sustainability of education in Indonesia. Education is one of the fields that is also affected by the industrial revolution. Therole of education in providing knowledge and experience related to mastery of soft skills and technology in developing human resources' quality must go well. Mastery of soft skills and technology is indeed the demand for generation $\mathrm{Z}$ in today's digital era. The form of effort in adapting to the digital era in education is through the internalization of the values of independence integrated with technological developments. The educational institution that has internalized independence values on their students is pondok pesantren.

In order to develop the quality of human resources, especially generation $Z$, the learning activities are in the form of training to improve soft skills and mastery of technology following the vision of 21 st-century learning. The vision of 21 st-century learning is that the students are required to have the knowledge, study skills, life skills, innovation, and abilities in technology, media, and information. However, in this research, it was found that efforts to internalize the values of independence in the Pondok pesantren environment for students or students were still not integrated with technology.

In essence, to develop the quality of human resources (students), the pondok pesantren chosen in this research were the ones which has internalized the values of independence in entrepreneurship education. Competition and changes that occur in a multidimensional context require students' abilities to do various jobs. The knowledge, skills, and attitudes obtained and developed from the pondok pesantren only emphasized Islamic education and cultural heritage, often considered incompatible with the demands of the students' higher competency needs when the students come to the community. Entrepreneurship was taught in the form of knowledge and direct practice in the socio-economic aspect. It would be more useful than just information and knowledge imparted to students. Entrepreneurship education applied in pondok pesantren began with the cultivation of fundamental entrepreneurial values based on Islam.

Entrepreneurship education has been implemented by the eight pondok pesantren chosen in this research. Based on interviews with the respondents, it was concluded that the pesantren residents synergized with each other to internalize the values of independence. The following are the results of interviews with the respondents. Interviews with $\mathrm{KH}$ Fathul Yasin as the head of Pondok Pesantren Kazunnajah Batu Malang, conveyed the importance of entrepreneurship education for students in pondok pesantren from an early age as a provision for them when they graduate and return to 
their hometowns. Pondok pesantren Kazunnajah invited students to practice entrepreneurship directly. Several examples of entrepreneurship activities managed by the students of the pondok pesantren Kazunnajah, among others, were cultivating orchids for sale, cultivating fresh fish, and selling handicrafts.

Prof. Dr. Ir. Mohammad Bisri, MS, as the head of Pondok Pesantren Bahrul Maghfiroh conveyed students' interest and independence in entrepreneurship at pondok pesantren. Most of the santri had a high interest in entrepreneurship, but the interest was low in most pondok pesantren with santri aged around ten. It was influenced by mental and emotional readiness in managing business. In addition to the students' interest in entrepreneurship, self-efficacy also influenced students to develop and recognize their potential in entrepreneurship through particular abilities and experiences continuously.

\begin{tabular}{|c|c|c|c|}
\hline $\begin{array}{l}\text { Problem and problem } \\
\text { discovery (Enter) }\end{array}$ & $\begin{array}{l}\text { Conduct qualitative data } \\
\text { collection } \\
\text { (Process) }\end{array}$ & $\begin{array}{c}\text { Analyze problems and } \\
\text { problems } \\
\text { (Process) }\end{array}$ & $\begin{array}{c}\text { Present findings related } \\
\text { to problems and issues } \\
\text { (Output) }\end{array}$ \\
\hline
\end{tabular}

Figure 1. Simple research design on the internalization of the value of independence in pondok pesantren (Taufik, 2013)

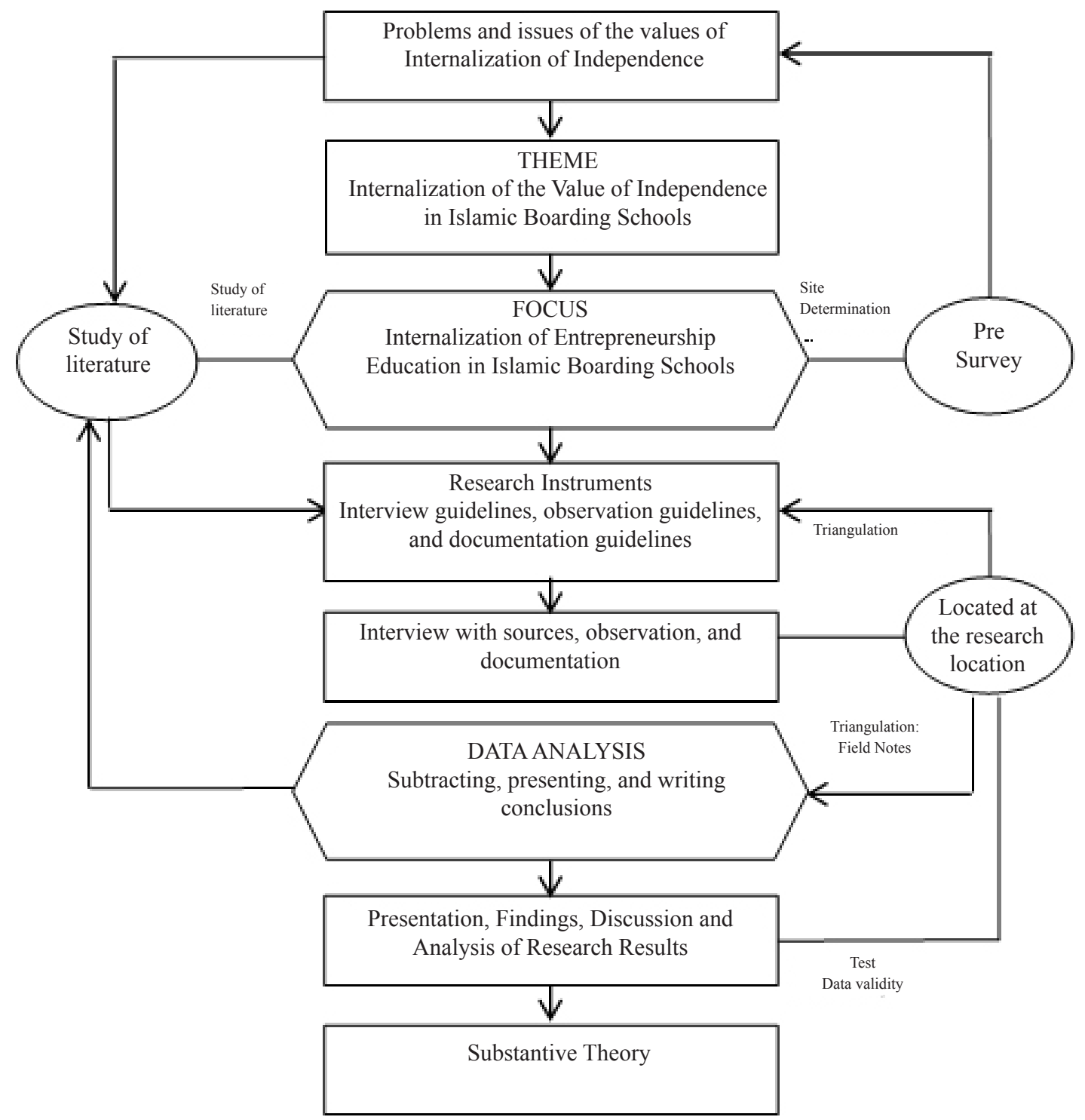

Figure 2. Stages of qualitative research design on the internalization of self-reliance value in pondok pesantren (Taufik, 2013) 
The integration between entrepreneurship education and the interest in entrepreneurship can build the students' potentials to achieve independence. It is in line with the head of Pondok Pesantren Nurul Ulum Malang (Astri, M.Pd), who stated that interest in entrepreneurship, self-efficacy, family support, and consistency in running a business could help in controlling oneself when experiencing failure in entrepreneurship. The business would have the opportunity to grow rapidly. The realization of the success of Pondok Pesantren Nurul Ulum Malang was in its ability to manage various businesses, including building rental, Islamic entertainment services (hadrah), and cooperatives, which were simultaneously managed by pondok pesantren and the santri.

In order to strengthen the results of interviews, the santri were also interviewed regarding the internalization of independence-value and entrepreneurial interests. According to the santri, mastery of technology in all fields is a challenge and a new culture for Indonesian people. As students, becoming financially independent graduates is one of the visions of pondok pesantren. Therefore the vision is balanced with learning more about the use of technology. Santri, as generation Z, must be able to compete in the digital era.

Based on the research, efforts to internalize the values of independence in the digital era were important things that must be done by pondok pesantren. Pondok pesantren's role was educating and shaping the santri's characters to become nationalist, versatile (skilled), and independent with a foundation of faith and mastery of applied science in a balanced manner. Through the characters, pondok pesantren is now starting to be overlooked for its participation in preparing the nation's young generation.

Therefore, efforts to internalize the values of independence in the digital era by pondok pesantren in Malang Raya were integrated into santripreneurship, santri-based entrepreneurship (Prihatminingtyas, 2016). Santripreneurship was a small and medium industrial development program (SMEs) in pondok pesantren environment. The program was initiated by the Ministry of Industry to realize the independence of the national industry based on the sharia economy. It was fully supported by the Directorate General of IKM of the Ministry of Industry in Surabaya by fostering thematic training tailored to industrial units' needs and potentials in several pondok pesantren from 2013 to
2015. Due to this program, pesantren have received support from the government, especially the Ministry of Industry, in developing the santri's entrepreneurial potential. According to the Ministry of Religion, there were 27,290 pondok pesantren in Indonesia in 2014 with 3.65 million. The figure had the potential to grow new entrepreneurs and SMEs in Indonesia (Ministry of Industry, 2017).

Basically, santripreneurship and entrepreneurship have similarities in terms of realizing financial independence through entrepreneurial activities, but they are different in terms of actors who carry out entrepreneurial activities. Theoretically, entrepreneurship is done by people who are experts or business practitioners. They become experts because they have gone through many stages in running entrepreneurship to find a formula to be stable and develop well. Entrepreneurship carried out by santri is often referred to as santripreneurahip (Syarif et al. 2016). Santriprenurship has been carried out in several pondok pesantren in Malang Raya. In line with the results of interviews and field observations, entrepreneurship education also develops students' potential tohaveindependenceandahighentrepreneurial spirit. To create santri who have an entrepreneurial spirit, they must be equipped with life skills so that they are able to develop their skills into a business field both for themselves and for others. Responding to this, the Deputy for Human Resources Development of the Ministry of Cooperatives and SMEs RI made it happen in the Santri Business Practices management program (TPUS). In the Strategic Plan of Islamic Education 20102014, pesantren education had the following missions: (1) Building a religious tradition based on classical literature (Pole Al-turats) and contemporary literature (Pole Al-'ashriyyah) through recitation activities (Baths Al-polar) and study (Baths Al-masail); (2) Developing the potential for thinking and working and responding to developments in science and technology; (3) Providing entrepreneurship education with a variety of skills (life skills) following the development of society.

Based on the information shared by from Dr. Riyanto, M.Hum as the Director of UB TV through a webinar, Pondok Pesantren Bahrul Maghfiroh had a strategy to strengthen its financial management so that it continues to run well to support the independence of the pesantren, which is guided by the 7A (7 Al-Fatihah) principles. It is one of the pesantren strategies in facing the digital era. It could also be that several other pondok pesantren had strategies and solutions that 
were more effective in overcoming problems caused by the industrial revolution. Still, the main thing that must be maintained by pondok pesantren is educating and guiding students to become independent youths and have noble characters according to Islamic teachings.

Efforts to foster an entrepreneurial spirit by internalizing independence values in the digital era for santri had several supporting and inhibiting factors. Some of the supporting factors included the achievement of the application of independent character values as input for efforts to internalize the values of independence and the achievement of the implementation of the curriculum, which required students to be independent and religious. Pondok pesantren contributed to forming the character of independent santri through santripreneurship. Dhofier (2015) stated that in recent developments, the boarding school education system has undergone a convergence process and can at least be classified into five types, namely: (1) Pondok pesantren providing formal education by applying the national curriculum, both of which only have religious schools at the same time public school; (2) Pondok pesantren providing religious education in the form of madrasah and teach general sciences even though they do not apply the national curriculum; (3) Pondok pesantren that only teach religious knowledge in the form of Madrasah Diniyyah; (4) Pondok pesantren which are only used as places of recitation (majlis taklim); (5) Pondok pesantren variations that can be seen from various angles to produce detailed categorizations: (1) In a series of curricula, pondok pesantren is divided into three types, namely modern pondok pesantren, pondok pesantren for tahassus, and mixed pondok pesantren; (2) In its development based on the content of the curriculum, pondok pesantren is also divided into three types, namely the simplest pondokpesantren, the middle pondok pesantren, and the most advanced pondok pesantren; (3) Judging from the number of students and their influence, pondok pesantren is divided into three types, namely small pondok pesantren, middle pondok pesantren, and large pondok pesantren; (4) Judging from the scientific specifications, pondok pesantren is divided into four types, namely pondok pesantren for equipment, pondok pesantren for fiqh, pondok pesantren for qira'ah, and pondok pesantren for Sufism; (5) Judging from the types of students, there are special pondok pesantren for toddlers, pondok pesantren for parents, pondok pesantren for students, and general pondok pesantren. This research focused on general pondok pesantren and pondok pesantren for students; (6) Judging from the tendency of socioreligious organizations, there are pondok pesantren NU, pondok pesantren Muhammadiyah, pondok pesantren Persis, and neutral pondok pesantren; (7) In terms of the developed education system, there are three kinds of pondok pesantren; (8) There are five elements of pondok pesantren; (9) Institutions related to the teaching system are of five categories; and (10) In terms of openness to change, there are pondok pesantren salafi and khalafi.

In addition to supporting factors, efforts to internalize the values of independence in the digital era had threats in the form of inhibiting factors if the santri had low entrepreneurial enthusiasm and were influenced by the poor facilities provided by pondok pesantren to develop theirentrepreneurial potential. Therefore, internalization needs to be evaluated. The evaluation is to determine the santri's level of interest in entrepreneurship from a young age. It can be concluded that most of the santri preferred to serve in the pondok pesantren by running a business that has been run by the pondok pesantren over returning to their hometown or starting to become santripreneurs,

In addition, this study found that the process of creating a culture in the form of values, beliefs, habits, and philosophies was instilled by the kiai through several activities, including admitting new students. In the socialization process, kiai was a model for the santri. The position of kiai was the most important element in the pesantren in its capacity as a designer (architecture), founder and developer, and as leader and manager of the pesantren (Dhofier, 2105). This study's results were in accordance with Pertiwi et al. (2018) stating that kiai is the main figure obeyed by the santri, because the kiai is known as the highest leader and founder of the pesantren. In leading the pesantren, kiai used different leadership styles according to the community's sociocultural conditions. Kiai defined leadership in pesantren as an "art" in utilizing all the strengths (funds, facilities, and human resources) of the pesantren to achieve the objectives of the pesantren (Mastuhu,1994). In shaping the personality of the santri, kiai provided a lifestyle in the form of ways of applying an entrepreneurial spirit by giving knowledge about economic management. According to Ahmad (2016), kiai would provide guidelines for building economic stability, especially in this digital era that must be supported by Islam's most basic pillars: faith, sharia, and morals. 
Based on the research results, it can be concluded that entrepreneurial santri must be able to interpret independence through self-confidence with the support of the role of the kiai, who can provide a mindset that their lives will be happy in the hereafter. Most santri who have completed their studies at pondok pesantren would serve the kiai because it is a tradition that has been passed down until now. The facilities provided to develop their entrepreneurial spirit were also supported by direct training/practice in several businesses managed by pondok pesantren so that the santri would have the spirit of freedom to choose businesses that were in accordance with their fields after they graduated.

\section{Managerial Implications}

This study's results are expected to be useful to increase the understanding of various parties, including pondok pesantren, researchers, and academics. For pondok pesantren, the results can be used as materials for consideration and evaluation of motivation, opportunities, processes, problems, and characters of an entrepreneurial spirit for students who have graduated or have not graduated. For researchers, the results can provide information by being directly involved through observations related the influence of the kiai's leadership and the formation of the entrepreneurial spirit applied in pondok pesantren in real conditions. Given that researchers are prospective educators with basic entrepreneurship, they can later provide good quality in running their business. For academics, the results are expected to enrich knowledge and complement the literature on how to internalize the values of independence in students.

\section{CONCLUSIONS AND RECOMMENDATION}

\section{Conclusions}

This study generated the finding that efforts to internalize the independence values on the santri in today's digital era are critical. The urge to internalize the independence values received a good response from the pondok pesantren residents in Malang Raya, mostly from the santri as the implementation target. Efforts to internalize the independence values ran effectively along with the inculcation of good moral values and religious values applied by the pesantren. Several pondok pesantren in Malang Raya have designed various efforts to support the pondok pesantren's independence, both for the pondok pesantren and for its residents. Based on the findings, several types of businesses have been running in several Pondok pesantren in Malang Raya, namely businesses in agriculture, animal husbandry, food processing, and handicrafts. However, several business developments were integrated with technology, namely printing and broadcasting business, such as providing image and video production services. The managers of these various entrepreneurial activities were all pondok pesantren residents, especially santri, who were expected to become independent individuals after graduating from the pesantren. However, business skills were cultivated through assignments in assisting businesses in pesantren, such as processing products and services and pesantren cooperatives, but still conventionally, such as providing image and video production services.

\section{Recommendations}

Efforts to internalize the values of independence in the digital era in pondok pesantren should be more integrated with current technology mastery. Due to the rapid changes in the digital era, santri must have a more advanced mindset with mastery of technology even though limited by the internet use rules in pondok pesantren. It is intended that santri can compete in the digital era. Entrepreneurial activities carried out by several pondok pesantren in Malang Raya have been running quite well. Still, it should start integrating technology by looking at marketing opportunities, constantly innovating products, and creating an easily accessible platform to the public to increase income. The role of pondok pesantren residents and the support of the santri guardians to develop their potential to become entrepreneurs are important in realizing independence values.

\section{REFERENCES}

Abdullah M, Osman K. 2010. 21st century inventive thinking skills among the major students in Malaysia and Brunei. Procedia - Social and Behavioral Sciences 9: 1646-1651. https://doi. org/10.1016 / j.sbspro. 2010.12.380.

Ahmad MA. 2016. Liberalization of Islam in Pondok pesantren(Reflections on Santri Thought). Pasuruan: Sidogiri Library, Sidogiri Islamic Boarding School.

Alma B. 2018. Entrepreneurship for Students and the 


\section{General. Bandung: Alfabeta.}

Cho SY et al. 2018. The MERS-CoV outbreak following a exposure to one patient in an emergency room in South Korea: epidemiological outbreak studies. Lancet 388: 994-1001.

Creswell JW. 2012. Educational Research, Planning, Implementation and Quantitative and Qualitative Evaluation (Four). Boston: Pearson.

Dhofier Z. 2015. The Tradition of the Pondok pesantrenThe Study of the Kiai's Life View and His Vision of the Period Indonesia front. Jakarta: LP3ES.

Mastuhu. 1994. Dynamics of Pondok pesantren Education System. Jakarta: Inis.

Matthew B, Miles A, Huberman M. 1994. Qualitative Data Analysis. London: Sage Publication.

Nafi D et al. 2007. Pondok pesantrenLearning Praxis. Yogyakarta: PT. LKiS Pelangi Aksara.

Ministry of Education and Culture. 2018. Improving the Learning Process and Assessment of 21st Century Learningin improving the Quality of Defendersjaran SMK. Jakarta: Ministry of Education and Culture.

Ministry of Industry. 2017. Santripreneur Creating a Sharia-Based Economy. https://www. kemenperin.go.id/artikel/18398/SantripreneurWujud-Ekonomi- Sharia-based [5 Aug 2020].

Kupperschmidt BR. 2000. Multigenerational employees: Strategies for Effective Management. Health Care Managers 19(66): 65-76.

Lordoglu K, Ozkaplan N, Toruner M. 1999. Calısmaiktisadı, Beta Book, 3. Istanbul:Bask1.
Pertiwi et al. 2018. Leadership of Kiai: Descriptive Study. Advances in Social Sciences, Education and Humanities Research 269 (1).

Prihatminingtyas B. 2016. Santripreneurship-Based Economic Empowerment. Proceedings 1st International Pondok pesantrenconference UIN Maulana Malik Ibrahim Malang: UIN Maulana Malik Ibrahim Malang.

Prisgunanto I. 2014. Digital Marketing Era Communications: WOMM, IMC, Era 4.0, strategy-tactics, intimacy \& media convergence. Jakarta: Prisani Cendekia.

Ruskovaara E, Pihkala T. 2015. Entrepreneurship education in schools: empirical e vi d e n c e about the role of the teacher. Journal of Educational Research 108 (3): 236249.

Safko L. 2010. Social Media Bible: Tactics, Tools \& Strategies for Business Success. 2.nd.ed. New Jersey: John Wiley.

Schlechtendahl J et al. (2015). Making it exist Industry 4.0-ready production system. Production Engineering 9(1):143-148.

Syarif Z et Al. (2016). Entrepreneurship-Based Pesantren. Proceedings of the International Conference I Pondok pesantren Maulana Malik Ibrahim Malang: UIN Maulana Malik Ibrahim Malang.

Taufiq R. 2013. Management Information Systems, Basic Concepts, Analysis and Methods Development. Yogyakarta: Graha Science.

Yin RK. 2002. Case Study Design and Research Methods (Five). London: Sage Publications. 